\title{
Export Growth and Poverty Reduction in Nigeria
}

\author{
Ovikuomagbe Oyedele ${ }^{1}$ and Uduakobong Eddy-Ewoh ${ }^{2}$ \\ ${ }^{I}$ University of Ibadan, Ibadan, Nigeria PhD Economics Student Under the African Economic Research \\ Consortium (AERC)Collaborative PhD Programme, Nairobi, Kenya \\ ${ }^{2}$ Babcock University, Ilishan-Ramo, Ogun state, Nigeria Assistant Lecturer in the Department of Economics, \\ Banking and Finance, Babcock Business School
}

\begin{abstract}
This study examines the effect of the growth of total exports on poverty reduction in Nigeria for the period 1980 to 2010. Using the ordinary least squares (OLS), after correcting for stationarity and heteroskedasticity biases, the results show that the growth rate of total export value or earnings is positively significant to explain changes in the real gross domestic product per capita used as a proxy for poverty. Thus an increase in the total export value increases the real gross domestic product per capita and thus reduces poverty. The total export volume however is not significant. Separating the total export volume into oil and nonoil exports, nonoil export growth was found to have a positive effect on the real gross domestic product per capita while the effect of oil export growth is negative. However, both were insignificant. The study concludes that a diversification of Nigeria's export from the predominantly oil exports to incorporate nonoil exports that have a higher export value going by the world market price is expedient.
\end{abstract}

Keywords: poverty reduction, export volume, export value, Nigeria, real gross domestic product per capita

\section{Introduction}

The first of the Millennium Development Goals (MDGs) is to eradicate poverty and hunger. This shows the severity of the challenge worldwide and its importance for development. Between 1980 and 2001, the percentage of Nigeria's population in dare poverty has increased from a sheer 26 per cent to about 70 percent (Ehigiene, 2007).

From the World Development Indicators 2012, Nigeria's total export volume has not experienced a steady growth since 1980. A lot of declines has occurred with the greatest decline of 51 per cent taking place in 1986. From 1999 to 2002, there was a consistent decline of 15 percent to 13 per cent. Oil export constitute a greater percentage of total export with nonoil exports suffering from a lack of attention. Most of the nonoil total exports are natural resources or primary goods which generally have low world market prices compared to manufactured goods. The real Gross domestic per capita experienced a steady decline from 1980 to 1987. A consistent increase has been maintained since 1996; however, its growth has been minimal with a maximum of about 7 per cent in 2003 and 2004. The objective of this study is to examine the impact of Nigeria's export growth on poverty levels. It also examines the impact of her export earnings on poverty levels. A justification for this study is the fact that despite several studies on poverty in Nigeria (Okojie 2002, Ogwumike, 2002, and Okuneye, 2002), most of these studies have focused on economic growth effects, unemployment effects, gender and education effects among others with few studies on the export growth effects (Vos et al. 2004, Schreckenberg et al. 2006) though not for Nigeria. This study also examines the effect of two major components of Nigeria's export - oil and nonoil on poverty reduction. The study covers the period from 1980 to 2010.

\section{Literature Review}

The extent and magnitude of absolute poverty in developing countries have attracted much attention especially with respect to measuring poverty. Four measures of poverty including the headcount index, total poverty gap index, the Foster, Greer and Thorbecke (FGT) index and the human poverty index are discussed in Todaro and Smith (2009). The headcount index is the number of people whose income falls below the absolute poverty line. The total poverty gap measure the total amount of income necessary to raise all persons who are below the poverty line up to that line. Several empirical studies have shown that export growth has an impact on poverty. Using data from 16 Latin American countries and employing a Computable General Equilibrium (CGE) model, Vos et al. (2004) examined the impact of export-led economic strategies on poverty and inequality and found that unilateral trade liberalization reduces poverty but raising tariffs increases it. Acrossthe-board, increases in export subsidies was found to be generally poverty reducing with a few exceptions. The impact of export growth on poverty was found to be positive but small. It also found that devaluation and low productivity increase poverty. Emphasis on the need for countries to formulate policies that would enhance increased domestic and foreign income earnings from its indigenous abundant resource. For instance, the 
indigenous fruit trees in Nigeria and Cameroon provide large income to households and communities, thus contributing to poverty reduction; as alternative sources of traditional diet thus improving the nutritional and health status of households, they also have non-income related positive impacts on poverty (Schreckenberg et al. 2006).

One major cause of high poverty levels is the neglect of the agricultural sector. Studies such as Okuneye (2002) show that the neglect of this food production sector in the form of lack of investment and technological improvement is responsible for the rising cost of food prices and the resulting poverty. $\mathrm{He}$ emphasizes that increasing the export of agricultural products is important for poverty reduction since agriculture provides employment for up to $70 \%$ of the labour force in rural areas.

On the determinants of poverty rates, Ghura et al. (2002) identified inflation and government balance relative to GDP (capturing macroeconomic stability), inequality level, natural resources availability and labour productivity in agriculture, institutions and governance, human development, financial sector development and physical capital as very core. They argued that countries with rents from natural resources that appropriate such rents to a few section of the population only increase the poverty rate while increased participation in agriculture could reduce rural poverty. They also emphasized that having the right institutions that promote freer markets, strong property rights, economic reforms and policies towards income redistribution and equity would reduce poverty. The level of human development which they captured by the life expectancy rate and the school enrolment rate are seen to empower labour thus increasing labours earning ability. Finally, they opine that the ease of accessing credit and having an enabling environment for investment in form of adequate infrastructure are paramount for poverty reduction. Using per capita expenditure as a proxy for poverty, Okojie, (2002) found gender and education as significant determinants of household poverty in Nigeria such that while increased education reduced poverty, female headed households and larger households were more likely to be poor. On the way forward, Ogwumike, (2002) states that asset redistribution and creation of incentive structures towards improving the rate and pattern of economic growth is a broader element in a sustainable poverty reduction strategy than a focus on social welfare measures.

\section{Theoretical Framework}

Todaro and Smith (2010) expansiate on the measures of absolute poverty which include the headcount index, total poverty gap Foster-Greer-Thorbecke (FGT) index and the human poverty index. The criteria for a desirable poverty measure include anonymity, population independence, monotonicity and distributional sensitivity. The first two measures emphasize that poverty measures should not be based on population size or who is poor in a country. Monotonicity principle explains that adding income to someone below the poverty line, other incomes held constant, poverty can be no greater than it was. The distributional sensitivity principle emphasizes that transferring income from a poor to a rich person makes the economy even strictly poorer. Whilst the headcount index shows the fraction of the population whose income fall below the poverty line, the total poverty gap measures the total income amount needed to raise everyone below the poverty line to that line. The FGT index however is called the $\mathrm{P}_{\alpha}$ class of index and depending on the value of $\alpha$, we get the headcount index if $\alpha=0$ and the normalized poverty gap if $\alpha=1$. if $\alpha=2$, the impact of a gain in income by a poor person increases in proportion to the distance of the person from the poverty line. The FGT satisfies all four criteria amongs theses three income poverty measures. It would therefore be more applicable in this study.

The fourth measure shifts away from the income poverty measure to measure human poverty focusing on three key deprivations - life expectancy, basic education and economic provisioning. It therefore combines health, education and overall basic amenities such as water, food etc.

Using the income poverty measure and leaning on the FGT index, this study proxies poverty using the real gross domestic product per capita.

\subsection{Data and Source}

\section{Methodology}

The data used for the study include the real per capita GDP used as a proxy for the poverty level, growth rate of total exports, trade tariffs which capture custom and excise duties paid on exports and imports, public investment expenditures and inflation rate. The data are from the World Development Indicators 2012 and the Central Bank of Nigeria Statistical Bulletin 2011. Based on availability, the time series data are for the period 1980 to 2010 .

\subsection{Model Specification}

There are different ways to measure poverty among which are poverty head count index, poverty gap, real per capita income, real per capita consumption, suffering index, etc. This study however employs real per capita income as a proxy for poverty since data for this variable is consistently available for the period under 
study. This measure has been variously and extensively used and would to a large extent, capture change in income poverty for the period under consideration.

The poverty framework focuses on how to improve the real per capita income level. We specify two models that explain the determinants of poverty taking into consideration the unique impact of total export growth in the first model and oil and nonoil export growth in the second model. The linear functional form is given as:

RGDPPC $=f(E G, T A R, E V G$, PIEG, INF $)$

RGDPPC $=\mathrm{f}($ OG, NOG, TAR, EV, PIEG, INF $)$

Model I

The equation for model $I$ therefore is given as:

Model II

RGDPPC $=\alpha+\beta_{1} \mathrm{EG}+\beta_{2} \mathrm{TAR}+\beta_{3} \mathrm{EV}+\beta_{4} \mathrm{PIEG}+\beta_{5} \mathrm{INF}+\varepsilon$

Apriori, $\beta_{1}>0, \beta_{2}<0, \beta_{3}>0, \beta_{4}>0, \beta_{5} \mathrm{INF}<0$

The equation for model II therefore is given as:

RGDPPC $=\alpha+\beta_{1} \mathrm{OG}+\beta_{2} \mathrm{NOG}+\beta_{3} \mathrm{TAR}+\beta_{4} \mathrm{EVG}+\beta_{5} \mathrm{PIEG}+\beta_{6} \mathrm{INF}+\varepsilon$

Apriori, $\beta_{1}>0, \beta_{2}<0$, and $\beta_{3}>0, \beta_{4}>0, \beta_{5}>0, \beta_{6}<0$

RGDPPC is the real gross domestic product per capita which is used as a proxy for poverty. EG represents total export growth rate which is expected to have a positive effect on real per capita income. OG stands for oil export growth rate while NOG represents the total nonoil export growth rate. TAR represents trade tariffs in form of customs and excise duties. High tariffs would discourage exports by reducing the amount of exportable goods produced which in turn would reduce the real per capita income and increase poverty (Vos et al. 2004). EVG represents the growth of total export value or earnings and this is expected to positively impact on per capita income. PIEG represents public investment expenditure growth which provides the enabling environment for increased investment and output growth thus, increasing the per capita income. INF stands for inflation which generally reduces the purchasing power of income.

\subsection{Descriptive Statistics of Data}

\section{Estimation Results}

As shown in Table 1 below, the mean real GDP per capita for the period 1980 to 2010 is 381.65 ; with a maximum and minimum of 544.6 in the year 2010 and 293.6 in the year 1984 respectively. Total export volume has a mean of 1.907419 while the mean of total export value is 8.476774 . The total number of observations is 31.

Table 1 Descriptive Statistics of Data

\begin{tabular}{|l|r|r|r|r|r|r|r|r|}
\hline Variables & \multicolumn{1}{|l}{ RGDPPC } & \multicolumn{1}{l|}{ INF } & \multicolumn{1}{l}{ TAR } & \multicolumn{1}{l}{ PIEG } & \multicolumn{1}{l|}{ EG } & \multicolumn{1}{l|}{ NOG } & \multicolumn{1}{l|}{ OG } & \multicolumn{1}{l|}{ EVG } \\
\hline Mean & 381.65 & 20.95 & 8285.96 & 427.42 & 1.91 & 39.29 & 39.01 & 8.48 \\
\hline Median & 366.50 & 16.20 & 1813.50 & 26.64 & 3.17 & 16.83 & 22.23 & 4.18 \\
\hline Maximum & 544.60 & 83.60 & 63000.00 & 12554.69 & 51.29 & 331.78 & 362.14 & 77.04 \\
\hline Minimum & 293.60 & -5.60 & 57.70 & -51.92 & -50.80 & -42.79 & -40.80 & -61.23 \\
\hline Std. Dev. & 62.42 & 20.16 & 15713.54 & 2251.16 & 21.73 & 87.96 & 80.22 & 32.93 \\
\hline Skewness & 1.00 & 1.21 & 2.48 & 5.29 & -0.17 & 2.31 & 2.61 & 0.23 \\
\hline Kurtosis & 3.34 & 4.34 & 8.20 & 29.01 & 3.18 & 7.48 & 10.47 & 2.65 \\
\hline
\end{tabular}

N/B: number of observations is 31 .

\subsection{Stationarity Test}

Using the Augmented Dickey-Fuller unit root test, a stationarity test was conducted for all variables in models I and II. All variables were found to be stationary at levels except real GDP per capita and trade tariffs which are stationary at first difference as shown below.

Table 2 Stationarity Test Results

\begin{tabular}{|c|c|c|c|}
\hline Variables & Levels & $\begin{array}{l}\text { First } \\
\text { difference }\end{array}$ & $\begin{array}{l}\text { Order of } \\
\text { integration }\end{array}$ \\
\hline RGDPPC & 1.333 & -4.815 & $\mathrm{I}(1)$ \\
\hline INF & -4.005 & Nil & $\mathrm{I}(0)$ \\
\hline TAR & -2.313 & -5.147 & $\mathrm{I}(1)$ \\
\hline PIEG & -5.473 & Nil & $\mathrm{I}(0)$ \\
\hline EG & -4.731 & Nil & $\mathrm{I}(0)$ \\
\hline
\end{tabular}




\begin{tabular}{|l|l|l|l|}
\hline NOG & -6.08 & Nil & $\mathrm{I}(0)$ \\
\hline OG & -5.96 & Nil & $\mathrm{I}(0)$ \\
\hline EVG & -5.193 & Nil & $\mathrm{I}(0)$ \\
\hline & & & \\
\hline $\begin{array}{l}\text { critical values at } \\
\text { levels }\end{array}$ & $\begin{array}{l}\text { critical values at } \\
1 \text { st difference }\end{array}$ & & \\
\hline $1 \%-3.670$ & $1 \%-3.679$ & & \\
\hline $5 \%-2.964$ & $5 \%-2.968$ & & \\
\hline $10 \%-2.621$ & $10 \%-2.623$ & & \\
\hline
\end{tabular}

\subsection{Cointegration Test}

Testing for cointegration using the Johansen cointegration test, the trace statistic and Eigen values show that there is no cointegration among the non-stationary variables.

\subsection{Heteroskedasticity Test}

Employing the Breusch-Pagan/Cook-Weisberg test for heteroskedasticity, the study rejected the null hypothesis of no heteroskedasticity with a chi-sqaure value of 2.82 significant at $10 \%$ for model I using export volume growth. In the case of model II using oil and nonoil export volume growth, the null hypothesis of no heteroskedasticity was also rejected with a chi-square of 3.39 significant at $10 \%$. Thus, controlling for heteroskedasticity, robust standard errors are used.

\subsection{Ordinary Least Squares Regression for Models I and II} Table 3 OLS Regression Estimates Using Robust Standard Errors:Dependent Variable: Real Gross Domestic Product Per Capita

\begin{tabular}{|c|c|c|c|}
\hline \multicolumn{4}{|c|}{ Coefficients (t-statistic) } \\
\hline & & Regression 1 & Regression 2 \\
\hline & $\mathrm{D}(\mathrm{TAR})$ & $0.000(0.18)$ & $0.000(0.15)$ \\
\hline & INF & $-0.174(-1.23)$ & $-0.182(-1.17)$ \\
\hline & EG & $0.060(0.23)$ & NIL \\
\hline & PIEG & $0.001(1.26)$ & $0.001(1.62)$ \\
\hline & EVG & $0.238(2.20)^{* *}$ & $0.275(2.06)^{* * *}$ \\
\hline & $\mathrm{NOG}$ & NIL & $0.024(0.44)$ \\
\hline & OG & NIL & $-0.024(-0.51)$ \\
\hline & F-STATS & 10.79 & 6.882 \\
\hline & PROB $>F$ & 0 & 0.0003 \\
\hline & R-SQUARED & 0.207 & 0.208 \\
\hline
\end{tabular}

$* *$ and *** represent significance at the $5 \%$ and $10 \%$ levels

\subsection{Model I}

\section{Discussion Of Results}

From Table 3 above, only the growth rate of export value is significant at the 5 per cent level to explain changes in the real gross domestic product per capita, thus reducing poverty levels. The total export volume is not significant even though it has a positive sign as expected. Inflation has a negative effect on the real gross domestic product per capita. Surprisingly, tariff has a positive though insignificant effect indicating that a rise in customs and excise duties improves the real gross domestic product per capita. This could be explained by the higher quantity of imports relative to exports applicable in the Nigerian case such that the customs and excise duties have a larger share of import tariffs than export. High import tariffs would reduce the import level and inducee domestic production as a replacement thus improving the real gross domestic product per capita. From the F-statistic, the overall significance of the model is high at the 1 per cent level.

\subsection{Model II}

Separating the total export volume into oil exports and nonoil exports, the OLS results show that only the growth of total export value is positively significant at the 10 per cent significant level in explaining changes in the real gross domestic product per capita. This result still confirms the importance of increases in the money worth of total exports (and not just the total volume or quantity) in improving the real gross domestic product per capita or reducing poverty levels. Nonoil total export volume has a positive effect while the volume of oil 
exports has a negative effect on the real gross domestic product per capita. Although both of them are insignificant, we can deduce that increasing the nonoil sector export which actually provides more labour market opportunities for employment than just the oil sector would increase the real gross domestic product per capita and thus reduce poverty levels.

\section{Conclusion}

A conclusive point is the fact that monetary value rather than the volume of total exports is of more importance in the strive to reduce poverty. Thus, a high volume of exports with a little value going by the world market price does not aid poverty reduction. Nigeria must therefore diversify her exports to include high priced goods at the world market by depending less on primary product exports and encourage the export of manufactured products. There is also the need to diversify exports so as to increase the volume of nonoil exports which have a positive impact on poverty reduction as shown in the results. It is therefore pertinent to increase efforts towards export promotion policies.

\section{References}

[1]. Ghura, D., Leite, C. A. and Tsangarides, C. (2002) "Is Growth enough? Macroeconomic Policy and Poverty Reduction" International Monetary Fund Working Paper, (WP/02/118)

[2]. Vos, R., Ganuza, E., Morley, S., Robinson, S. and Pinero, V. (2004) "Are Export Promotion and Trade Liberalization Good for Latin America's Poor? A Macro-Micro Computable General Equilibrium Analysis” Institute of Social Studies Working Paper Series Number 399

[3]. Schreckenberg, K., Awono, A., Degrande, A., Mbosso, C., Ndoye, O. and Tchoundjeu, Z. (2006) "Domesticating Indigenous Fruit Trees as a contribution to Poverty Reduction" Forests, Trees and Livelihoods Vol.16, pp.35-51.

[4]. Okuneye, P. A. (2002) "Rising Cost of Food Prices and Food Insecurity in Nigeria and its Implication for Poverty Reduction" Central Bank of Nigeria Economic and Financial Review Vol. 39 Issue4.

[5]. Todaro, M. P. and Smith, S. C. (2009) "Economic Development" (10th ed.) Addison-Wesley

[6]. Okojie, C.E. (2002) "Gender and Education as Determinants of Household Poverty in Nigeria" United Nations University World Institute for Development Economics Research (UNU-WIDER) Discussion Paper Number 2002/37

[7]. Ogwumike, F. O. (2002) "An Appraisal of Poverty Reduction Strategies in Nigeria" Central Bank of Nigeria Economic and Financial Review Vol. 39 Issue 4. 